\title{
Studies on soil quality indices and agricultural functionality potentials of Ariara Market Solid Waste Dumpsite Aba, Abia State, Nigeria
}

\author{
G. C. Chinyere*, O. R. Chima Ezika and K. U. Osuocha \\ Department of Biochemistry, Abia State University, Uturu, Nigeria
}

\begin{abstract}
Soil physicochemical properties and selected enzyme activities were assessed at thirteen different points at a depth of $0-45 \mathrm{~cm}$ (sample A) and 46-90cm (sample B) from Ariara Market solid waste dump site Aba, Abia State. Control samples were collected 100m away from discharge point devoid of solid waste impaction. The studied points were discharge point (DC), 4 meters away East (E1), West (W1), North (N1), and South (S1) from the center of the dumpsite and 8 meters away East (E2), West (W2), North (N2) and South (S2) from the center of the dumpsite. Results indicated an alkaline $\mathrm{pH}$ for all the studied points. Significantly high $(\mathrm{p}<0.05)$ temperatures and percentage moisture contents were also obtained at the discharge points (DC) of the dumpsite compared to control points. Similarly, dumpsite alkaline phosphatase, hydrogen peroxidase, dehydrogenase and urease activities were significantly $(\mathrm{p}<0.05)$ higher than those of control points at $0-45 \mathrm{~cm}$ depth (sample A). These finding suggest that wastes from this dumpsite could be harnessed as biofertilizers for agricultural purposes.
\end{abstract}

Key words: Soil quality; agricultural potentials; Ariara market

\section{Introduction}

In most developing countries like Nigeria, waste dumping and accumulation is an everincreasing problem throughout the country. The constituents of wastes depend on the location and nearby people [1]. This could mean that the composition of waste dumps in urban settings is greater than those in the rural areas. This dumping habit not only decrease the aesthetic view of the country but also increasing disease carrying vectors. These dumpsites also attract scavengers who often remove non-degradable materials while the rest are often set on open burning in order to reduce the volume. An earlier report, [2] showed the implication of cultivation and harvesting of vegetables grown in the dumpsites in Abia State, Nigeria. In that report, edible vegetables were noted to contain at high levels toxic metals observed from these dumpsites. Similarly, the burning of waste on dumpsites leads to production of toxic chemicals which may inhibit microbial activities. Microorganisms are essentials for degradation of waste and increase in soil fertility. These they achieve through the release of various enzymes into the soil. The release of nutrients at the time of decomposition of wastes is almost similar in effect to that of other organic manures [3]. These nutrients may enrich the soil and soil microorganism thereby improving the soil characteristics. The organic matter decomposition depends upon the soil enzymes in the soil system [3]. They catalyse the

\footnotetext{
Received o9 November 2017; Accepted 27 December 2017; Published 29 December 2017

*Corresponding Author

G. C. Chinyere

Department of Biochemistry, Abia State University, Uturu, Nigeria

Email: gcchinyere@yahoo.com

(OThis article is open access and licensed under the terms of the Creative Commons Attribution License (http://creativecommons.org/licenses/by/4.o/) which permits unrestricted, use, distribution and reproduction in any medium, or format for any purpose, even commercially provided the work is properly cited. Attribution - You must give appropriate credit, provide a link to the license, and indicate if changes were made.
} 
organic waste decomposition and releasing of important nutrients back to the soil [4]. These enzymes regularly being synthesized in soil and got accumulated and play a significant role in recycling of major nutrients [4]. All soils contain a group of enzymes that determines soil metabolic processes which in turn depend on its inherent physical, chemical, microbiological and biochemical properties [4]. Better understanding about the activities and production rate of these important nutrient releasing activities are necessary in soil management and preservation and there by supporting the sustainable agricultural practices [5]. Soil enzymes measurement is a sensitive indicator of alteration of soil quality through management. Factors that affect the soil fauna and flora critically affects the soil enzyme activities. This study therefore focuses on the impact of Ariara market solid waste dumping on soil quality through soil enzyme analyses.

\section{Method of analysis \\ Soil sample collection}

Twenty six (26) soil samples were used for the analysis. Two soil samples each were collected from 13 different points considered from the studied waste dumpsite`s vicinity. The soil samples were collected using plastic auger at the depths of $0-45 \mathrm{~cm}$ and $46-90 \mathrm{~cm}$. Collection points were the center of the dumpsite (DC), 4 meters away East $\left(\mathrm{E}_{1}\right)$, West $\left(\mathrm{W}_{1}\right)$, North $\left(\mathrm{N}_{1}\right)$, and South $\left(\mathrm{S}_{1}\right)$ from the center of the dumpsite and 8 meters away East $\left(\mathrm{E}_{2}\right)$, West $\left(\mathrm{W}_{2}\right)$, North $\left(\mathrm{N}_{2}\right)$ and South $\left(\mathrm{S}_{2}\right)$ from the center of the dumpsite. The controls soil samples were taken at 100 meters away from the dumpsite center East $\left(\mathrm{E}_{3}\right)$, West $\left(\mathrm{W}_{3}\right)$, North $\left(\mathrm{N}_{3}\right)$, and South $\left(\mathrm{S}_{3}\right)$. The collected soil samples were placed in covered plastic plates and were properly labelled.

\section{Preparation of soil sample}

The soil samples were air-dried, mechanically grounded using a stainless steel roller, mortar and pestle. The grounded soil was sieved to obtain $<2 \mathrm{~mm}$ fraction and stored at $4^{\circ} \mathrm{C}$

\section{Physicochemical parameters determination}

Temperature of the soil samples and $\mathrm{pH}$ were determined in situ using the JENWAY multipurpose tester HANNA 1910 as described by APHA [6]. Soil moisture was determined using the method described by APHA [6].
Cation exchange capacity was determined by the method of Dewis and Freitas [7], while exchangeable acidity determinations was done using the method as described in AOAC [8].

\section{Soil enzymes}

The activities of soil dehydrogenase, acid phosphatase and alkaline phosphatase were determined using the methods of Tabatabai [9]. Soil hydrogen peroxidase and protease were estimated by the methods of Alef and Nannipieri [10,11] while soil urease was determined by the method of Tabatabai and Bremner [12].

\section{Statistical analysis}

Data collected were subjected to statistical analysis using one-way analysis of variance (ANOVA) procedure. The student package for social sciences (SPSS) version 20 computer software was used for the analysis.

\section{Results and discussion}

Soil temperature is known to play crucial roles in soil biochemical processes [13,14]. In this study (Table 1) soil temperature of the dumpsites ranged from $25.8^{\circ} \mathrm{C}$ to $36.4^{\circ} \mathrm{C}$. At o$45 \mathrm{~cm}$, the soil temperature was significantly higher $(\mathrm{p}<0.05)$ compared to the other depth $(46-90 \mathrm{~cm})$. This difference in soil temperature with soil depth may have resulted from decaying debris by microbes. The highest values of temperature were observed at the centre of the dumpsite (DC). The significant increase $(p<0.05)$ in temperature of dumpsite centre (DC) compared to other sampling points in the present study could be attributed to biogeochemical reactions due to degradation of large volume of wastes at the centre of the dump. Temperature rise in soil has been reported to increase metal activity in soil solutions as well as absorption rate in plants through higher evaporation and transpiration from plants [15]. Akubugwo et al. [17] noted that soil $\mathrm{pH}$ is the master variable that affects virtually all soil properties. Soil $\mathrm{pH}$ influences a number of factors affecting soil fertility such as solubility and ionization of inorganic and organic soil solution constituents and these will in turn affect soil enzyme activity. The $\mathrm{pH}$ of $\mathrm{o}-$ $45 \mathrm{~cm}$ soil depth was significantly $(\mathrm{p}<0.05)$ higher than the $\mathrm{pH}$ obtained for $46-90 \mathrm{~cm}$ soil depth in all the sampling points. The reduction in the $\mathrm{pH}$ with increased soil depth might be due to possible concentration of the contaminant down the soil depth. Result indicates an alkaline $\mathrm{pH}$ generally in all the 
sampling points relative to control. It has been noted that nature and biodegradation of wastes generate compound which dissolves in soil moisture to affect the soil $\mathrm{pH}$ [17]. Acidic $\mathrm{pH}$ in solid waste dumps sites soils are usually as a result of metal scraps [15]. It has been shown that acidic soils increase the availability of some metals which may build to toxic levels in soil and increase heavy metal phytoavailability [18]. Most crops thrive at $\mathrm{pH}$ 6.2 -6.8 as obtained here and attest to the potential usage of this soil for agricultural purposes as the $\mathrm{pH}$ obtained from this study are within the FEPA acceptable limit for agricultural soils. Soil moisture (Table 1) also followed the same pattern observed for soil temperature and $\mathrm{pH}$ in this study. Seasonal changes are known to affect dumpsite soil moisture contents [2]. Similarly binding of the soil by wastes at dumpsite (DC), which reduced pore spaces, may aid the insufficient aeration of the soil and affect the overall predisposition of the area under study. Findings generally indicate increase in soil moisture with increasing soil depth.

Tables 1. Physicochemical characteristics of Ariara Market solid waste dump soil.

\begin{tabular}{|c|c|c|c|c|c|c|}
\hline Site & $\begin{array}{l}\text { Temp }{ }^{\circ} \mathrm{C} \\
\text { Sample A }\end{array}$ & $\begin{array}{c}\text { Temp }{ }^{\circ} \mathrm{C} \\
\text { Sample B }\end{array}$ & $\begin{array}{l}\mathrm{pH} \\
\text { sample A }\end{array}$ & $\begin{array}{l}\mathrm{pH} \\
\text { sample B }\end{array}$ & $\begin{array}{l}\text { \% moisture } \\
\text { Sample A }\end{array}$ & $\begin{array}{l}\text { \% moisture } \\
\text { sample B }\end{array}$ \\
\hline $\mathrm{DC}$ & $36.4 \pm 1.00^{c}$ & $36.0 \pm 1.01^{c}$ & $6.8 \pm 0.08^{b}$ & $6.0 \pm 0.11^{a}$ & $65.50 \pm 0.11^{a}$ & $44.90 \pm 0.90^{c}$ \\
\hline $\mathrm{E}_{1}$ & $31.4 \pm 0.02^{b}$ & $30.1 \pm 0.47^{b}$ & $6.5 \pm 0.01^{\mathrm{a}}$ & $5.8 \pm 0.02^{a}$ & $24.22 \pm 0.29^{c}$ & $29.11 \pm 0.21^{b}$ \\
\hline $\mathrm{E}_{2}$ & $30.2 \pm 1.02^{c}$ & $29.3 \pm 0.02^{b}$ & $6.2 \pm 0.00^{\mathrm{a}}$ & $5.5 \pm 0.07^{b}$ & $20.00 \pm 0.07^{b}$ & $21.21 \pm 0.01^{\mathrm{a}}$ \\
\hline $\mathrm{E}_{3}$ & $28.4 \pm 0.11^{\mathrm{a}}$ & $26.7 \pm 0.92^{c}$ & $6.1 \pm 0.79^{c}$ & $5.4 \pm 0.81^{\mathrm{c}}$ & $14.21 \pm 0.00^{\mathrm{a}}$ & $16.28 \pm 0.01^{\mathrm{a}}$ \\
\hline $\mathrm{W}_{1}$ & $30.4 \pm 0.02^{b}$ & $29.1 \pm 0.21^{b}$ & $6.4 \pm 0.08^{b}$ & $5.0 \pm 0.79^{c}$ & $22.41 \pm 0.48$ & $25 \cdot 72 \pm 1.00^{\mathrm{a}}$ \\
\hline $\mathrm{W}_{2}$ & $29.8 \pm 0.91^{c}$ & $28.9 \pm 1.00^{c}$ & $6.1 \pm 0.09^{b}$ & $5.0 \pm 0.01^{\mathrm{a}}$ & $18.31 \pm 0.01^{\mathrm{a}}$ & $20.61 \pm 0.08^{b}$ \\
\hline $\mathrm{W}_{3}$ & $28.3 \pm 0.01^{\mathrm{a}}$ & $26.6 \pm 0.22^{\mathrm{a}}$ & $6.1 \pm 0.01^{\mathrm{a}}$ & $5.4 \pm 0.00^{\mathrm{a}}$ & $15.20 \pm 0.08^{b}$ & $17.11 \pm 0.01^{\mathrm{a}}$ \\
\hline $\mathrm{N}_{1}$ & $32.4 \pm 0.02^{b}$ & $30.6 \pm 0.11^{\mathrm{a}}$ & $6.0 \pm 0.01^{b}$ & $5.4 \pm 0.21^{c}$ & $16.31 \pm 0.48^{\mathrm{c}}$ & $23.73 \pm 0.21^{b}$ \\
\hline $\mathrm{N}_{2}$ & $30.1 \pm 0.91^{c}$ & $29.4 \pm 0.02^{b}$ & $6.0 \pm 0.22^{\mathrm{a}}$ & $5.2 \pm 0.11^{\mathrm{a}}$ & $15.42 \pm 0.44^{c}$ & $22.61 \pm 0.22^{b}$ \\
\hline $\mathrm{N}_{3}$ & $27.6 \pm 0.79^{c}$ & $25.8 \pm 0.01^{\mathrm{a}}$ & $6.3 \pm 0.01^{\mathrm{a}}$ & $5.8 \pm 0.47^{\mathrm{c}}$ & $9.30 \pm 0.00^{\mathrm{a}}$ & $12.5^{2} \pm 0.11^{b}$ \\
\hline $\mathrm{S}_{1}$ & $31.3 \pm 0.78^{c}$ & $29.9 \pm 0.89^{c}$ & $6.1 \pm 0.37^{c}$ & $5.0 \pm 0.21^{b}$ & $15.70 \pm 0.27^{c}$ & $20.80 \pm 0.00^{a}$ \\
\hline $\mathrm{S}_{2}$ & $28.6 \pm 0.91^{c}$ & $27.5 \pm 0.01^{\mathrm{a}}$ & $5.9 \pm 0.22^{b}$ & $5.1 \pm 0.00^{\mathrm{a}}$ & $14.18 \pm 0.11^{\mathrm{b}}$ & $20.00 \pm 0.11^{\mathrm{a}}$ \\
\hline $\mathrm{S}_{3}$ & $28.4 \pm 0.01^{\mathrm{a}}$ & $28.0 \pm 0.00^{a}$ & $6.0 \pm 0.11^{\mathrm{a}}$ & $5.6 \pm 0.01^{\mathrm{a}}$ & $15.74 \pm 0.08^{b}$ & $18.20 \pm 0.00^{a}$ \\
\hline
\end{tabular}

Values are mean of triplicate determination \pm standard deviation. Values in the column having the same superscript are not significant $\mathrm{P}<0.05$.

A= Soil sample collected $0-45 \mathrm{~cm} ; \mathrm{B}=$ Soil sample collected $46-90 \mathrm{~cm}$; DC=Discharge point

$E_{1}, W_{1}, N_{1}, S_{1}=4 m$ away from discharge point, Eastwards, Westwards, Northwards and Southwards.

$\mathrm{E}_{2}, \mathrm{~W}_{2}, \mathrm{~N}_{2}, \mathrm{~S}_{2}=8 \mathrm{~m}$ away from discharge point, Eastwards, Westwards, Northwards and Southwards

$\mathrm{E}_{3}, \mathrm{~W}_{3}, \mathrm{~N}_{3}, \mathrm{~S}_{3}=$ Result obtained for control samples, Eastwards, Westwards, Northwards and Southwards

Table 2. Cation exchange capacities and exchangeable acidities of Ariara solid waste soils.

\begin{tabular}{lllll}
\hline Sites & $\begin{array}{l}\text { CEC }(\mathrm{mol} / \mathrm{kg}) \\
\text { Sample A }\end{array}$ & $\begin{array}{l}\text { CEC }(\mathrm{mol} / \mathrm{kg}) \\
\text { Sample B }\end{array}$ & $\begin{array}{l}\text { EA (meq) } \\
\text { Sample A }\end{array}$ & $\begin{array}{l}\text { EA (meq) } \\
\text { Sample B }\end{array}$ \\
\hline $\mathrm{DC}$ & $0.03 \pm 2.3 \times 10^{-3 \mathrm{~b}}$ & $0.02 \pm 2.1 \times 10^{-3 \mathrm{a}}$ & $4.0 \pm 0.03^{\mathrm{c}}$ & $8.0 \pm 0.01^{\mathrm{a}}$ \\
$\mathrm{E}_{1}$ & $0.04 \pm 1.2 \times 10^{-3 \mathrm{c}}$ & $0.01 \pm 1.0 \times 10^{-3} \mathrm{a}$ & $3.2 \pm 0.02^{\mathrm{d}}$ & $4.8 \pm 0.01^{\mathrm{a}}$ \\
$\mathrm{E}_{2}$ & $0.02 \pm 2.2 \times 10^{-3 \mathrm{a}}$ & $0.01 \pm 3.3 \times 10^{-3} \mathrm{a}$ & $3.6 \pm 0.03^{\mathrm{b}}$ & $4.0 \pm 0.01^{\mathrm{a}}$ \\
$\mathrm{E}_{3}$ & $0.05 \pm 1.0 \times 10^{-3 \mathrm{~b}}$ & $0.03 \pm 3.1 \times 10^{-3 \mathrm{~b}}$ & $3.6 \pm 0.03^{\mathrm{c}}$ & $3.8 \pm 0.01^{\mathrm{a}}$ \\
$\mathrm{W}_{1}$ & $0.06 \pm 1.2 \times 10^{-3 \mathrm{~b}}$ & $0.03 \pm 2.7 \times 10^{-3 \mathrm{~b}}$ & $2.8 \pm 0.01^{\mathrm{a}}$ & $4.1 \pm 0.00^{\mathrm{a}}$ \\
$\mathrm{W}_{2}$ & $0.04 \pm 2.7 \times 10^{-3 \mathrm{c}}$ & $0.03 \pm 3.2 \times 10^{-3} \mathrm{a}$ & $3.8 \pm 0.01^{\mathrm{a}}$ & $3.4 \pm 0.01^{\mathrm{a}}$ \\
$\mathrm{W}_{3}$ & $0.04 \pm 1.1 \times 10^{-3 \mathrm{c}}$ & $0.02 \pm 1.2 \times 10^{-3 \mathrm{a}}$ & $3.4 \pm 0.02^{\mathrm{b}}$ & $4.0 \pm 0.00^{\mathrm{a}}$ \\
$\mathrm{N}_{1}$ & $0.04 \pm 3.2 \times 0^{-3 \mathrm{c}}$ & $0.03 \pm 7.1 \times 10^{-3 \mathrm{~d}}$ & $2.8 \pm 0.01^{\mathrm{a}}$ & $4.1 \pm 0.02^{\mathrm{b}}$ \\
$\mathrm{N}_{2}$ & $0.02 \pm 1.1 \times 10^{-3} \mathrm{e}$ & $0.02 \pm 1.1 \times 10^{-3} \mathrm{a}$ & $3.8 \pm 0.00^{\mathrm{a}}$ & $3.40 .00^{\mathrm{a}}$ \\
$\mathrm{N}_{3}$ & $0.04 \pm 2.0 \times 10^{-3 \mathrm{a}}$ & $0.03 \pm 2.9 \times 10^{-3} \mathrm{~b}$ & $3.4 \pm 0.02^{\mathrm{b}}$ & $4.0 \pm 0.01^{\mathrm{a}}$ \\
$\mathrm{S}_{1}$ & $0.03 \pm 7.0 \times 10^{-3 \mathrm{a}}$ & $0.01 \pm 3.3 \times 10^{-3 \mathrm{a}}$ & $3.5 \pm 0.02^{\mathrm{c}}$ & $4.1 \pm 0.02^{\mathrm{b}}$ \\
$\mathrm{S}_{2}$ & $0.02 \pm 2.6 \times 10^{-3 \mathrm{a}}$ & $0.01 \pm 7.2 \times 10^{-3 \mathrm{c}}$ & $2.9 \pm 0.01^{\mathrm{a}}$ & $3.2 \pm 0.00^{\mathrm{a}}$ \\
$\mathrm{S}_{3}$ & $0.04 \pm 1.2 \times 10^{-3 \mathrm{c}}$ & $0.02 \pm 3.6 \times 10^{-3}$ & $3.9 \pm 0.00^{\mathrm{a}}$ & $4.3 \pm 0.02^{\mathrm{b}}$ \\
\hline
\end{tabular}

Values are mean of triplicate determination \pm standard deviation. Values in the column having the same superscript are not significant $\mathrm{P}<0.05$.

A= Soil sample collected $0-45 \mathrm{~cm}$; B =Soil sample collected 46-90cm; DC=Discharge point

E1, W1, N1, S1= 4m away from discharge point, Eastwards, Westwards, Northwards and Southwards.

E2, W2, N2, S2=8Mm away from discharge point, Eastwards, Westwards, Northwards and Southwards $\mathrm{E}_{3}, \mathrm{~W}_{3}, \mathrm{~N}_{3}, \mathrm{~S}_{3}=$ Result obtained for control samples, Eastwards, Westwards, Northwards and Southward 
Table 3. Soil enzyme activities of Ariara Market dumpsite soils.

\begin{tabular}{|c|c|c|c|c|c|c|c|c|c|c|c|c|}
\hline Sites & $\begin{array}{l}\text { Acid } \\
\text { phospatase } \\
\text { ( } \mu \text { mol- } \\
\text { pnitrophenol) } \\
\text { Sample A }\end{array}$ & $\begin{array}{l}\text { Acid phospatase } \\
\text { ( } \mu \text { mol- } \\
\text { pnitrophenol) } \\
\text { Sample B }\end{array}$ & $\begin{array}{l}\text { Alkaline } \\
\text { Phosphatise } \\
\text { ( } \mu \text { mol- } \\
\text { pnitrophenol) } \\
\text { Sample A }\end{array}$ & 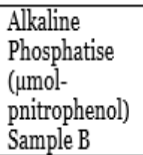 & $\begin{array}{l}\text { Hydrogen } \\
\text { peroxidase } \\
\left(\mathrm{Mlg}^{-1} \mathrm{~h}^{-1}\right) \\
\text { Sample A }\end{array}$ & $\begin{array}{l}\text { Hydrogen } \\
\text { peroxidase } \\
\left(\mathrm{Mlg}^{-1} \mathrm{~h}^{-1}\right) \\
\text { Sample B }\end{array}$ & $\begin{array}{l}\text { Dehydrogenase } \\
\text { mgTPFg-16h }^{1} \\
\text { SampleA }\end{array}$ & $\begin{array}{l}\text { Dehydrogenase } \\
\text { mgTPFg-16h }^{-1} \\
\text { Sample B }\end{array}$ & $\begin{array}{l}\text { Protease } \\
\mu t y r o s i n e ~ g-1 \\
\text { dwt } 2 h^{-1} \\
\text { Sample A }\end{array}$ & $\begin{array}{l}\text { Protease } \\
\mu \text { tyrosine g- }{ }^{-1} \\
{\text { dwt } 2 h^{-1}} \\
\text { Sample B }\end{array}$ & $\begin{array}{l}\text { Urease } \\
\mathrm{mgNH}_{3-} \\
\mathrm{NG}^{-1} 2 \mathrm{H}^{-1} \\
\text { Sample A }\end{array}$ & $\begin{array}{l}\text { Urease } \\
\mathrm{mgNH}_{3-} \\
\mathrm{NG}^{-1} 2 \mathrm{H}^{-1} \\
\text { Sample B }\end{array}$ \\
\hline $\mathrm{DC}$ & $3.1 \pm 1.00^{\mathrm{a}}$ & $3.8 \pm 0.01^{b}$ & $5.4 \pm 0.01^{\mathrm{c}}$ & $3.8 \pm 0.01^{\mathrm{a}}$ & $8.1 \pm 1.10^{\circ}$ & $7.4 \pm 0.01^{\mathrm{c}}$ & $13.8 \pm 1.00^{c}$ & $12.7 \pm 0.91^{\mathrm{c}}$ & $3.4 \times 10^{4}$ & $6.0 \times 1$ & $3.4 \pm 0.01 \mathrm{c}$ & $2.7 \pm 1.10 \mathrm{~b}$ \\
\hline$E_{1}$ & $3.7 \pm 0.02^{b}$ & $4 \cdot 1 \pm 0.47^{b}$ & $5.2 \pm 0.00^{c}$ & $3.6 \pm 0.02^{\mathrm{a}}$ & $6.1 \pm 0.50^{c}$ & $4 \cdot 3 \pm 0.01^{b}$ & $9.4 \pm 0.04^{c}$ & $7.1 \pm 0.01^{\mathrm{b}}$ & $2.4 \times 10^{4}$ & $3.8 \times 10^{4}$ & $2.4 \pm 0.01^{b}$ & $2.1 \pm 0.50^{\circ}$ \\
\hline $\mathrm{E}_{2}$ & $3.9 \pm 1.02^{\mathrm{b}}$ & $4.5 \pm 0.02^{b}$ & $4.1 \pm 0.01^{b}$ & $3.4 \pm 0.00^{\mathrm{a}}$ & $4.3 \pm 0.02^{b}$ & $3.1 \pm 0.00^{\mathrm{a}}$ & $4.4 \pm 0.01^{\mathrm{a}}$ & $3.9 \pm 0.04^{\mathrm{a}}$ & $1.7 \times 10^{4}$ & $1.9 \times 10^{4}$ & $2.0 \pm 0.00^{b}$ & $1.7 \pm 0.02^{\mathrm{a}}$ \\
\hline$E_{3}$ & $4.1 \pm 0.11^{\mathrm{b}}$ & $4.9 \pm 0.92^{c}$ & $3.4 \pm 0.01^{\mathrm{a}}$ & $3.0 \pm 0.01^{b}$ & $3.4 \pm 0.02^{\mathrm{a}}$ & $3.8 \pm 0.01^{\mathrm{a}}$ & $3.9 \pm 0.01^{\mathrm{a}}$ & $2.2 \pm 0.31^{\mathrm{a}}$ & $1.1 \times 10^{4}$ & $1.4 \times 10^{4}$ & $1.3 \pm 0.01^{\mathrm{a}}$ & $1.0 \pm 0.02^{\mathrm{e}}$ \\
\hline$W_{1}$ & $4.1 \pm 0.91^{b}$ & $4.4 \pm 1.00^{\mathrm{b}}$ & $4.1 \pm 0.00^{b}$ & $3.8 \pm 0.02^{b}$ & $6.3 \pm 0.03^{c}$ & $4.4 \pm 0.21^{b}$ & $10.3 \pm 0.91^{\mathrm{c}}$ & $7.4 \pm 0.21^{b}$ & $1.1 \times 10^{4}$ & $1.2 \times 10^{4}$ & & $3.8 \pm 0.03^{\mathrm{c}}$ \\
\hline $\mathrm{W}_{2}$ & $4.4 \pm 0.01^{\mathrm{c}}$ & $4.9 \pm 0.22^{\mathrm{c}}$ & $4.9 \pm 0.02^{\mathrm{c}}$ & $4.8 \pm 0.03^{c}$ & $3.7 \pm 0.01^{\mathrm{a}}$ & $2.6 \pm 0.01^{\mathrm{a}}$ & $4.8 \pm 0.02^{b}$ & $2.6 \pm 0.02^{\mathrm{a}}$ & $1.9 \times 10^{4}$ & $2.2 \times 10^{4}$ & & $3.6 \pm 0.01^{\mathrm{c}}$ \\
\hline $\mathrm{W}_{3}$ & $3.4 \pm 0.02^{\mathrm{a}}$ & $3.8 \pm 0.11^{\mathrm{b}}$ & $4.2 \pm 0.01^{\mathrm{b}}$ & $4.0 \pm 0.01^{b}$ & $3.8 \pm 0.00^{\mathrm{a}}$ & $4.1 \pm 0.31^{\mathrm{b}}$ & $3.4 \pm 0.03^{\mathrm{a}}$ & $2.6 \pm 0.01^{\mathrm{a}}$ & $8.5 \times 10^{4}$ & $1.4 \times 10^{4}$ & $1.6 \pm 0.31^{\mathrm{a}}$ & $1.5 \pm 0.00^{e}$ \\
\hline $\mathrm{N}_{1}$ & $3.5 \pm 0.91^{\mathrm{a}}$ & $4.1 \pm 0.02^{\mathrm{b}}$ & $4.1 \pm 0.02^{b}$ & $3.8 \pm 0.02^{b}$ & $4.7 \pm 0.01^{b}$ & $3.4 \pm 0.22^{\mathrm{a}}$ & $9.4 \pm 0.01^{\mathrm{c}}$ & $6.1 \pm 0.00^{b}$ & $2.6 \times 10^{4}$ & $3.7 \times 10^{4}$ & $3.8 \pm 0.22^{c}$ & $3.2 \pm 0.01^{\mathrm{c}}$ \\
\hline $\mathrm{N}_{2}$ & $4.2 \pm 0.79^{\mathrm{b}}$ & $4.9 \pm 0.01^{\mathrm{c}}$ & $4.9 \pm 0.00^{c}$ & $4.1 \pm 0.00^{\mathrm{a}}$ & $3.2 \pm 0.02^{\mathrm{a}}$ & $2.6 \pm 0.04^{\mathrm{a}}$ & $6.3 \pm 0.02^{b}$ & $4.1 \pm 0.02^{b}$ & $1.8 \times 10^{4}$ & $2.2 \times 10^{4}$ & $3.4 \pm 0.04^{c}$ & $2.8 \pm 0.02^{\mathrm{b}}$ \\
\hline $\mathrm{N}_{3}$ & & $3.8 \pm 0.12^{\mathrm{b}}$ & $4.4 \pm 0.03^{\mathrm{b}}$ & $3.9 \pm 0.01^{\mathrm{a}}$ & $3.9 \pm 0.03^{\mathrm{a}}$ & $4.3 \pm 0.01^{b}$ & $5.7 \pm 0.03^{\mathrm{b}}$ & $3.7 \pm 0.03^{\mathrm{a}}$ & $1.4 \times 10^{4}$ & & $1.8 \pm 0.01^{\mathrm{a}}$ & $1.4 \pm 0.03^{\mathrm{a}}$ \\
\hline $\mathrm{S}_{1}$ & $4.1 \pm 0.91^{b}$ & $4.6 \pm 0.01^{b}$ & $4.9 \pm 0.00^{c}$ & $3.7 \pm 0.02^{\mathrm{a}}$ & $4.2 \pm 0.01^{\mathrm{b}}$ & $3.8 \pm 0.12^{\mathrm{a}}$ & $10.4 \pm 0.91^{\mathrm{c}}$ & $6.1 \pm 0.01^{b}$ & 1. $2 \times 10^{4}$ & $1.7 \times 10^{4}$ & $3.6 \pm 0.12^{\mathrm{c}}$ & $3.1 \pm 0.01^{\mathrm{C}}$ \\
\hline $\mathrm{S}_{2}$ & $4.4 \pm 0.01^{\mathrm{b}}$ & $4.9 \pm 0.00^{c}$ & $5.3 \pm 0.01^{\mathrm{c}}$ & $3.1 \pm 0.01^{\mathrm{a}}$ & $3.1 \pm 0.01^{\mathrm{a}}$ & $2.8 \pm 0.21^{\mathrm{a}}$ & $7.1 \pm 0.21^{\mathrm{c}}$ & $3.7 \pm 0.02^{\mathrm{a}}$ & $1.3 \times 10^{4}$ & $1.3 \times 10^{4}$ & $3.0 \pm 0.21^{b}$ & $2.4 \pm 0.02^{\mathrm{b}}$ \\
\hline $\mathrm{S}_{3}$ & $3.0 \pm 0.78^{\mathrm{a}}$ & $3.9 \pm 0.89^{b}$ & $4.8 \pm 0.02^{\mathrm{c}}$ & $3.0 \pm 0.00^{\mathrm{a}}$ & $4.0 \pm 0.02^{b}$ & $4.3 \pm 0.02^{\mathrm{b}}$ & $3.2 \pm 0.01^{\mathrm{a}}$ & $2.1 \pm 0.00^{\mathrm{a}}$ & 1. $2 \times 10^{4}$ & 1. $6 \times 10^{4}$ & $2.0 \pm 0.02^{\mathrm{a}}$ & $1.4 \pm 0.02^{\mathrm{a}}$ \\
\hline
\end{tabular}

Values are mean of triplicate determination \pm standard deviation. Values in the column having the same superscript are not significant $\mathrm{p}<0.05$.

A= Soil sample collected $0-45 \mathrm{~cm}, \mathrm{~B}=$ Soil sample collected $46-90 \mathrm{~cm}$

$\mathrm{DC}=$ Discharge point, $\mathrm{E}_{1}, \mathrm{~W}_{1}, \mathrm{~N}_{1}, \mathrm{~S}_{1}=4 \mathrm{~m}$ away from discharge point, Eastwards, Westwards, Northwards and Southwards

$\mathrm{E}_{2}, \mathrm{~W}_{2}, \mathrm{~N}_{2}, \mathrm{~S}_{2}=8 \mathrm{~m}$ away from discharge point, Eastwards, Westwards, Northwards and Southwards

$\mathrm{E}_{3}, \mathrm{~W}_{3}, \mathrm{~N}_{3}$

Cations helps soil aggregation which reduces the chance of soil erosion and crusting. Exchangeable acidity of soils samples (Table 2) ranged from $0.01-0.06$ meq while cation exchange capacity (Table 2) ranged from 2.9$8.00 \mathrm{mg} / \mathrm{kg}$. The observed exchangeable acidity values of dumpsite (DC) in the present study were lower than those of the controls and the values increased with depth of samples collection. Increased level of exchangeable cations is synonymous with increase in pollution rate [13]. The cation exchange capacity obtained from the present study was highest at the dumpsite compared to control $(\mathrm{p}<0.05)$. Similar increases have been reported earlier [3,4]. It has been noted that cation exchange capacity gives the soil a buffering capacity. These will in effect slow the leaching of nutrient. This may be related to the observed higher values of cation exchange capacities for 46-90cm depth against those of $0-45 \mathrm{~cm}$ (Table 2). Soil enzymes activities influences functional processes occurring in soil and plays important role in catalysing chemical and biological processes necessary for soil microbes. Acid phosphatase activity (Table 3) was lowest at the dumpsite (DC) compared to other points in the present study. However, the activities of these enzymes increased $(p<0.05)$ with increase in depth of sample collection. This is in accordance with increase in soil acidity with depth of sample collection obtained here. Dehydrogenases are produced by all organisms and are intracellular
$[9,19]$ and serve as good measure of microbial oxidative activities in the soil [12] Dehydrogenase had high activities in the soil samples analysed in this study (Table 3). These increases in its activities at the dumpsites soils relative to control may be ascribed to increased nutrient availability indicating better conditions for microbial biodegradation of waste and release of plant nutrients. Dehydrogenase activities increased in $0-45 \mathrm{~cm}$ depth relative to $46-90 \mathrm{~cm}$ depth. Similar observations for dehydrogenase activities in refuse dumpsite soils was obtained by other workers $[1,20]$. The dumpsite (DC) had the highest hydrogen peroxidase activities than other points considered presently. Organic matter activates the activities of hydrogen peroxidase [19]. This probably explains its higher activities at $0-45 \mathrm{~cm}$ depth than 46 $90 \mathrm{~cm}$ depth in the present study. Urease activities in soils have been reported to play important roles in the regulation of nitrogen supply to plants [21,22]. Factors such as cropping history, organic matter content, soil depth, soil amendments, heavy metals, temperatures, etc, are among the factors that influence the urease activity in soil [23]. It has been suggested that the activity coefficient of urease increases with increase in temperature [23]. However, the low urease activity at dumpsite (DC) correlate positively with observed temperature of the dumpsite studied. The soil protease activity obtained was highest in dumpsite (DC). This probably due to organic 
debris from domestic refuse dumped there. The numerous leather materials at the dumpsite (DC) may have enhanced the protease activity. The enzyme activities can be influenced by changes in $\mathrm{pH}$ value, increasing water content and nutrient addition on soil [24].

The observation made from this work suggest that dumping of solid waste at Ariara market dumpsite generally affected the soil enzyme profile which may lead to increased plant nutrient availability. It is therefore recommended that adequate use of the soil for agriculture be made after proper treatment of the soil as to reduce possible contamination of plant products from it.

\section{References}

1. Olivera, A and Pampulha, D. Effect of long term heavy metal contamination on soil. Journal of Bioegertics, 2006. 102 (3): 151 $-161$.

2. Chinyere GC, Madu FU Physicochemical characteristics and heavy metal constituents of five dumpsite soils and edible vegetables grown in two major metropolis of Abia State, Nigeria. International Research Journal of Biochemistry and Biotechnology, 2015 2(2): 014-027.

3. Ubuoh E. A.., Akhionbare, W.N., Akhionbare, S.M.O., Akande, S.O.and Ikhile, C.I The potentials of solid wastes utilization for agriculture in Imo State, Nigeria. International Journal of Multidisciplinary Sciences and Engineering, 2012. 3(1):42-45

4. Dick, R. P., Breakwell, D.P and Turco, R. F Soil enzyme activities and biodiversity measurements as integrative microbiological indicators. In: Methods for Assessing Soil Quality, vol.9. Soil Sci. Soc. Am. Madison, WI, 1996: pp.9-17.

5. Chinyere, G.C., Nwankwo T.N and Osuocha K.U Studies on soil anions, cations and enzyme activities at Mgbunjuku- PortHarcourt, Nigeria. IOSR Journal of Environmental Science and Technology, 2013. 6(3):46-51

6. APHA Standards Methods for Examination of Water and Wastewater, Port City Press, Maryland USA. 1985

7. Dewis, J. and Freitas, F. Physical and chemical methods of soil and water analysis. Soil Bulletin, 10:1-275. FAO, Rome. 1970:
8. AOAC Association of Analytical Chemists, Official methods of Analysis. Washington, D.C. USA 2005:

9. Tabatabai, M. Soil enzymes In: Methods of soil analysis, part 2. Agronomy monograph, A.L (ed). American Society of Agronomy. Madison. 1982: pp. 903-904.

10. Alef, $K$ and Nannipieri, P. Method in applied soil microbiology and biochemistry. Academy Press New York. 1995: pp.214-218.

11. Nannipieri, P., Kandeler, E and Ruggiero, P. Enzyme activities and microbiological and biochemical process in soil. In: Burns, R.G. and R. Dick (Eds.) Enzyme in the environment. Marcel Delker, New York, 2002: pp. 1-33

12. Tabatabai, M. A and Bremner, J. M. Use of p-nitrophenylpospahte for assay of soil phosphate activity. Soil Biology and Biochemistry. .1972: 1:301-307.

13. Wyszkowska, J. and Kuchariski, J. Biochemical properties of soil contaminated by petrol. Journal of Environmental Studies. 2000: 9:479-485.

14. Chinyere, G.C., Obisike, E.S., Ugbogu, A.E. and Osuocha, K. U. Studies on municipal solid wastes dumping on soil anions, cations and selected enzymes activities at njoku sawmill waste dumpsite, owerri municipal, Imo State, Nigeria. Ethiopian Journal of Environmental Studies and Management, 2013. 6:774-789

15. Osuocha K U, Chukwu E C, Ugbogu E A, Atasie O C. and Ogbonna C E Effects of

16. quarry mining activities on the nutritional composition of edible vegetables in Ishiagu, Ebonyi State, Nigeria. Journal of Experimental Biology and Agricultural Sciences, 2016. 4(5):467-474.

17. Akubugwo, I. E., Ofoegbu, C.J., Dike, C.C and Ugbogu, A.E. Effect of mining operations on the physicochemical properties and microbial diversity of soil from Ishiagu, Ebonyi State, Nigeria. Journal of Applied and Environmental Sciences 2010: 6:46-51

18. Uba S, Uzairu A, Harrison GFS, Balarabe ML, Okunola OJ Assessement of heavy metals bioavailability in dumpsites of Zaira metropolis, Nigeria. African Journal of Biotechnology, 2008 7: 122-130.

19. Li, H., Zhang, Y., Zhang, C. G and Chen, G.X. Effects of petroleum containing waste water irrigation on bacterial diversities and 
enzymatic activities in a paddy soil irrigation area. Journal of Environmental Quality, 2005: 34:1073-1080.

20. Nwaogu, L.A., Ujowundu, C.O., Iheme, C.I., Ezejiofor, T.N.I and Belonwu, D.C Effect of sublethal concentration of heavy metal contamination on soil physicochemical properties, Catalase and Dehydrogenase activities. International Journal of Biochemistry Research and Review, 2014. 4(2): 141-149,

21. Simpson, J. R, Freney, J. R., Wetselaar, R., Muirhead, W. A., Leuning, R., and Denmead, O. T. Transformations and losses of urea nitrogen after application to flooded rice. Australian Journal of Agricultural Research, 1984: 35:189-200.

22. Simpson, J. R., Freney. J. R. Interacting processes in gaseous nitrogen loss from urea applied to flooded rice fields. In: Pushparajah E, Husin A, Bachik AT. (eds) Proceedings of international symposium on urea technology and utilization. Malaysian Society of Soil Science, Kuala Lumpur, 1988: pp 281-290.

23. Yang, Z., Liu, S., Zheng, D. and Feng, S. Effects of cadmium, zinc and lead on soil enzyme activities. Journal of Environmental Science, 2006: 18:11351141.

24. Lee, I.K., Chang, Y., Bac, B., Kini, H.H and Back, K. Heavy metal concentration and enzyme activities in soil from a contaminated Korean Shooting Range. Journal of Biosen and Biomonitoring, 2002 94:406-411. 